Gut, 1987, 28, S1 1-7

\title{
Effect of chronic bombesin on pancreatic size, composition and secretory function in the rat
}

\author{
C STOCK-DAMGE, E LHOSTE, M APRAHAMIAN AND A POUSSE
}

From the INSERM, Unit 61, Digestive Cell Biology and Physiopathology, Strasbourg, France.

SUMMARY Bombesin administered subcutaneously to rats, three times daily for four days, induces pancreatic growth at a dose of $10 \mu \mathrm{g} / \mathrm{kg}$. Growth was characterised by an increased pancreatic weight and content in protein and RNA, accompanied by cellular hypertrophy. Chronic bombesin also enhanced the pancreatic content in chymotrypsin and to a lesser degree its contents in amylase and lipase. The volume of the secretion and the output of enzymes in response to CCK under an infusion of secretin, however, remained unchanged although the functional capacity of individual cells to secrete amylase and lipase was reduced. It is concluded that chronic bombesin exerts a trophic action on the rat pancreas but decreases the sensitivity of each cell to hormonal stimulation.

Pancreatic growth is known to be influenced by a variety of factors including gastrointestinal hormones. Among these, cholecystokinin (CCK), gastrin, secretin and their structural analogues have been reported to exert a trophic action on the rat pancreas $^{1-5}$. Bombesin, a peptide isolated initially from the skin of the discoglossid frog Bombina bombina, has also been shown to induce pancreatic growth. ${ }^{5-7}$ This growth results from cellular hypertrophy or hyperplasia depending on the duration of treatment. ${ }^{7}$ The present work investigates the effects of a long term treatment of rats with bombesin on pancreatic size, composition and its secretory function studied in vivo and in vitro.

\section{Methods}

PEPTIDES

Bombesin tetradecapeptide was purchased from UCB Bioproducts (Paris, France). Cholecystokinin and secretin were kindly obtained from Kabi Vitrum (Paris, France).

\section{EXPERIMENTAL DESIGN}

In a first experiment, 32 male Wistar rats weighing $179 \pm 3 \mathrm{~g}$ were divided into four groups of eight rats each. Each rat received, three times daily and for four days, a $1 \mathrm{ml}$ subcutaneous injection of normal saline (controls) or bombesin at the following concentrations: $0 \cdot 1,1$ and $10 \mu \mathrm{g} / \mathrm{kg}$ body weight, in solution

Address for correspondence : C Stock-Damge, INSERM Unité de Recherches 61, 3, avenue Molière, 67200 Strasbourg, France. in $15 \%$ (wt/vol) hydrolysed gelatin. Animals were fed a standard rat chow diet ad lib (UAR, Villemoissonsur-Orge, France) and weighed every day. They were killed on day 5 after an overnight fast; pancreases were removed, trimmed from fat and lymph nodes, weighed and homogenised in ice cold pure water $(100 \mathrm{mg} / \mathrm{ml})$ in order to determine its size and composition.

In a second experiment, 12 rats weighing $178 \pm 2 \mathrm{~g}$ were injected according to the same schedule either with saline (controls) or bombesin $(10 \mu \mathrm{g} / \mathrm{kg}$ body weight). After a four day treatment, animals of both groups, fasted overnight, were killed on day 5. Each pancreas was separated in five fragments and incubated at $37^{\circ} \mathrm{C}$ for one hour in the absence of secretagogues (control) or in the presence of $10^{-10}$ and $10^{-8} \mathrm{M}$ caerulein or bombesin. The incubation medium, enriched by the L-amino-acid mixture of Campagne and Gruber ${ }^{8}$ and D-glucose $10 \mathrm{mM}$, was buffered with bicarbonate at $\mathrm{pH} 7 \cdot 4$. The gas phase was $\mathrm{O}_{2} 95 \%, \mathrm{CO}_{2} 5 \%$. The secretion of enzymes was quantified in aliquots from the medium.

In a third experiment, 12 rats weighing $467 \pm 8 \mathrm{~g}$, were injected subcutaneously, three times daily and for four days either with normal saline $(n=6)$ or with $10 \mu \mathrm{g} / \mathrm{kg}$ bombesin $(\mathrm{n}=6)$. In vivo secretory studies were performed on day 5 after an overnight fast in urethan $(0.1 \mathrm{~g} / 100 \mathrm{~g}$ body weight $)$ anaesthetised animals. The bile duct was ligated near the liver and the bile was derived into the duodenum using a polyethylene catheter (Biotrol, $0.96 \mathrm{~mm}$ oD). The main pancreatic duct was catheterised with a poly- 
ethylene catheter (Biotrol, $0.70 \mathrm{~mm}$ in external dicumeter) placed close to the duodenum. The right jugular vein was cannulated with an heparinised polyethylene tube (Biotrol, 0.96 mm oD) in order to administer secretagogues. Pancreatic juice was collected on ice in $20 \mathrm{~min}$ batches under continuous infusion of secretin ( 5 clinical units $/ h$ ) at a perfusion rate of $1 \mathrm{ml} / \mathrm{h}$; intravenous administrations of CCK $(1,5$, and 10 Ivy dog units (IDU) $/ \mathrm{kg}$ ) were performed at $80 \mathrm{~min}$ intervals. The volume of the secretion and its enzymatic composition were determined.

\section{BIOCHEMICAL ANALYSIS}

Aliquots from pancreatic homogenates, incubation mediums and pancreatic juice were analysed. Proteins were determined according to Bradford ${ }^{9}$ with bovine serum albumin as a standard. DNA and RNA were determined in pancreatic homogenates after extraction; the diphenylamine method using calf thymus DNA as a standard ${ }^{10}$ and the orcinol method using yeast RNA as a standard ${ }^{11}$ were used respectively. Amylase was estimated according to the method of Danielsson. ${ }^{12}$ Chymotrypsin was assayed as indicated by Nagel $e t a l^{13}$ and lipase according to Verduin et al. ${ }^{14}$

\section{STATISTICAL ANALYSIS}

For each parameter, the mean and standard error of the mean were calculated; for group comparisons a one way analysis of variance followed by a Student's unpaired $t$ test were applied.

\section{Results}

In each experiment, the body weight of animals increased approximately by $9.5 \%$ over the four day treatment with bombesin or normal saline.

\section{EFFECT OF CHRONIC BOMBESIN ON THE RAT} PANCREAS IN FUNCTION OF ITS DOSE

Results from the first experiment showed that bombesin administered subcutaneously at the dose of $10 \mu \mathrm{g} / \mathrm{kg}$, three times daily and for four days, induced a marked increase in pancreatic weight $(26 \%$, $\mathrm{p}<0.001)$ and its content in protein $(45 \%, \mathrm{p}<0.01)$ and RNA $(26 \%, p<0.05)$ (Fig. 1). Lower doses of bombesin $(0 \cdot 1$ and $1 \mu \mathrm{g} / \mathrm{kg})$ were without any effect on these parameters. The DNA content of the gland was never affected by bombesin treatment (Fig. 1) suggesting the absence of hyperplasia. The ratios of pancreatic weight, protein and RNA content to DNA content of the gland increased significantly in rats treated with $10 \mu \mathrm{g} / \mathrm{kg}$ bombesin suggesting cellular hypertrophy (Table). As illustrated in Figure 2, the pancreatic content in chymotrypsin, amylase and lipase increased respectively by $492 \%(p<0.01)$,

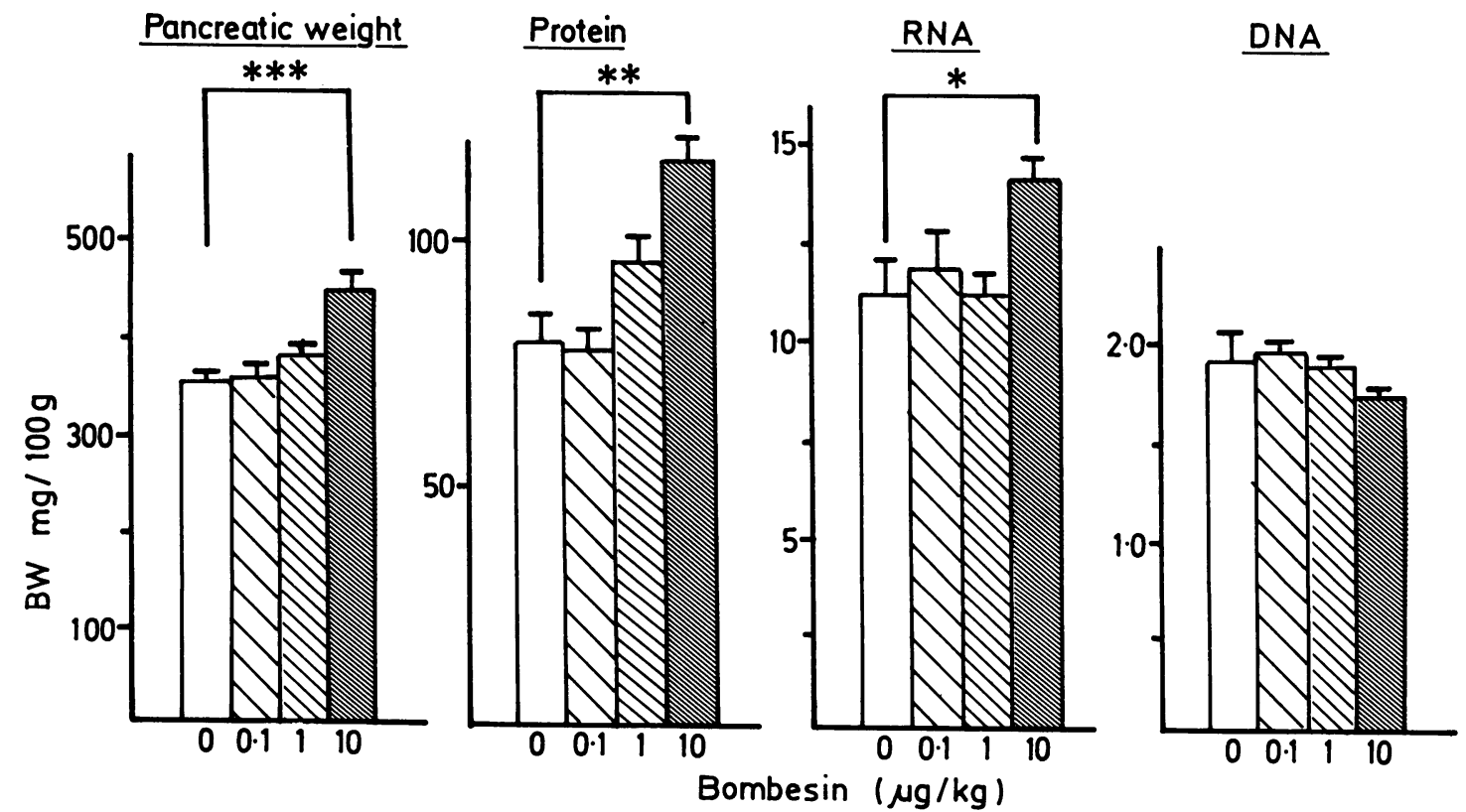

Fig. 1 Pancreatic weight, protein, RNA and DNA content after chronic administration of normal saline (open columns) and bombesin at the doses of $0 \cdot 1$ (sparsely hatched columns), 1 (moderately hatched columns) and 10 (heavily hatched columns) $\mu \mathrm{g} / \mathrm{kg}$. Results are means \pm SEM of 8 animals in each group. ${ }^{*} p<0.05,{ }^{* *} p<0.01,{ }^{* * *} p<0 \cdot 001$. 
Table. Indices of cellular hypertrophy in rats treated with bombesin $(0 \cdot 1,1$ and $10 \mu \mathrm{g} / \mathrm{kg})$. Values are ratios of treatment groups to control group. For individual rats, total $R N A$, protein and pancreatic weight in $\mathrm{mg}$ per $\mathrm{mg}$ of total DNA were calculated. Group means were computed and the ratios for these to the corresponding control mean were calculated. Values significantly greater than control (that is, 1.00): * $p<0.001$.

\begin{tabular}{llcl}
\hline & \multicolumn{3}{c}{ Bombesin $(\mu \mathrm{g} / \mathrm{kg})$} \\
& 0.1 & 1 & 10 \\
\hline Pancreatic weight/DNA & 0.97 & 1.08 & $1.46^{*}$ \\
Protein/DNA & 0.95 & 1.21 & $1.70^{*}$ \\
RNA/DNA & 1.04 & 1.04 & $1.52^{*}$ \\
\hline
\end{tabular}

$71 \%(\mathrm{p}<0.05)$ and $43 \%(\mathrm{p}<0.01)$ after a treatment with $10 \mu \mathrm{g} / \mathrm{kg}$ bombesin. Lower doses of bombesin did not change significantly the pancreatic enzyme content. When enzyme activities were expressed per $100 \mathrm{mg}$ of pancreas, there was a $380 \%$ increase $(\mathrm{p}<0.01)$ in chymotrypsin activity after a $10 \mu \mathrm{g} / \mathrm{kg}$ bombesin treatment. Other enzyme activities were not significantly altered.

\section{EFFECT OF CHRONIC BOMBESIN ON THE}

\section{SECRETORY FUNCTION OF THE RAT PANCREAS} STUDIED IN VITRO

As indicated in Figures 3 and 4, when pancreases from saline treated rats were incubated in vitro, only caerulein and bombesin at a $10^{-8} \mathrm{M}$ concentration induced a two to four-fold increase in the secretion of chymotrypsin and lipase and a two-fold increase in that of amylase when compared with unstimulated secretion. These results were quite similar when pancreases were provided from bombesin treated animals (Fig. 3).
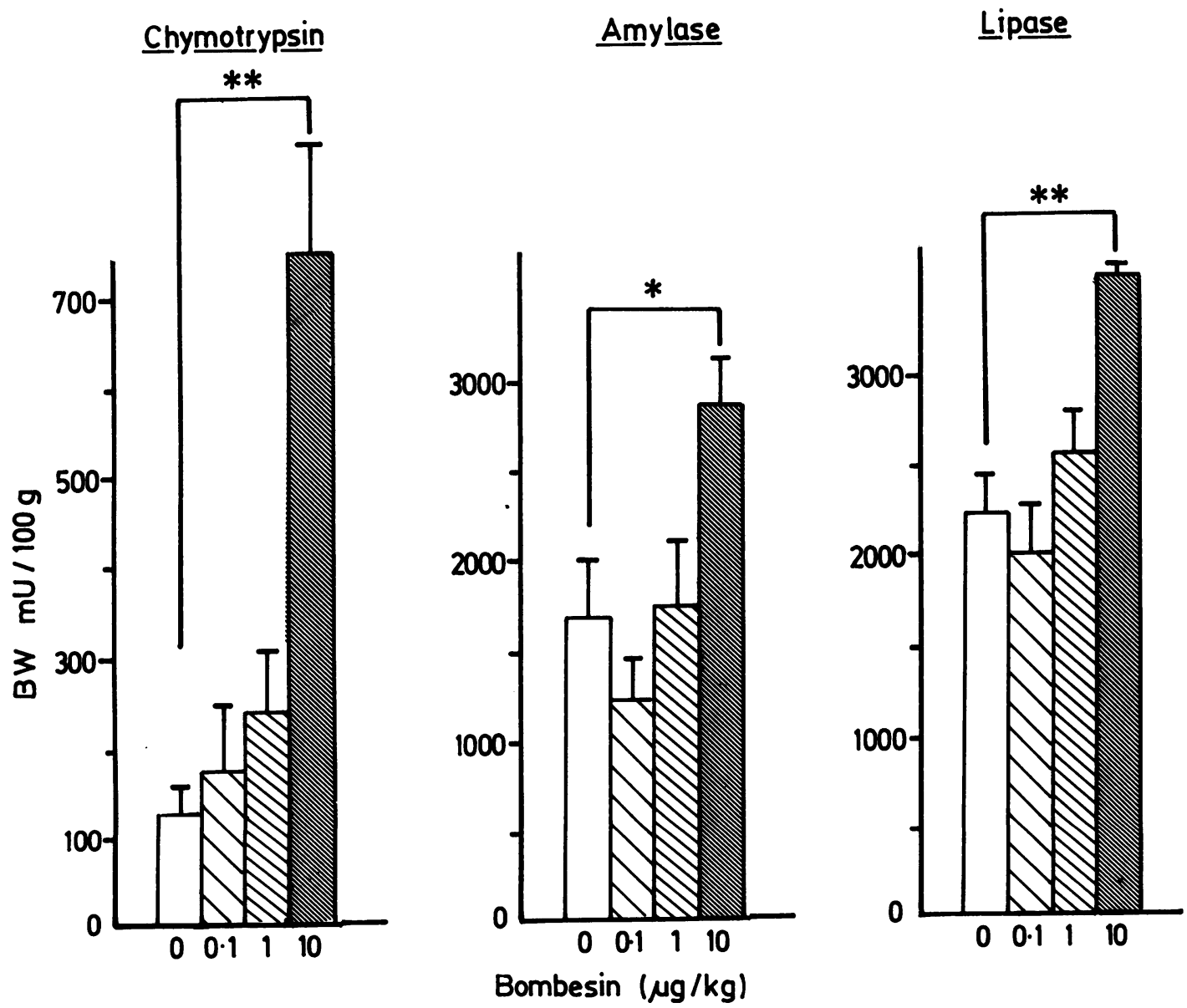

Fig. 2 Chymotrypsin, lipase and amylase content of the pancreas after chronic administration with normal saline (open columns) and bombesin at the doses of 0.1 (sparsely hatched columns), 1 (moderately hatched columns) and 10 (heavily hatched columns) $\mu \mathrm{g} / \mathrm{kg}$. Results are means $\pm S E M$ of 8 animals in each group. ${ }^{*} p<0.05,{ }^{* *} p<0.01$. 

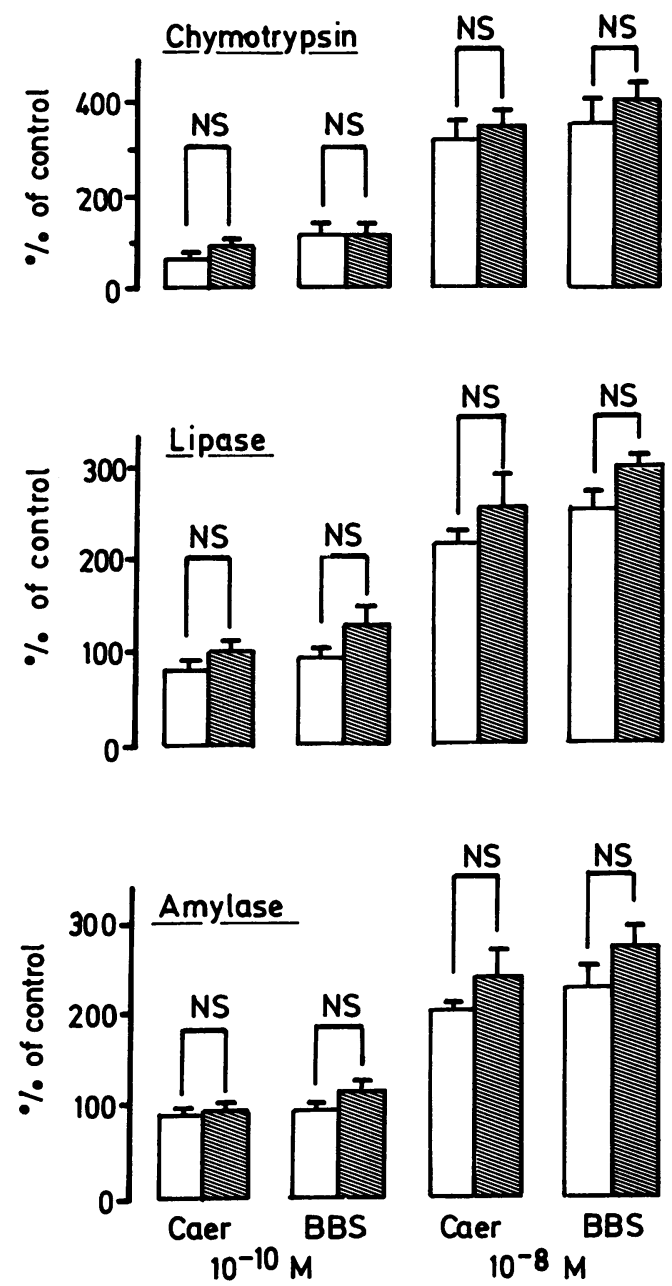

Fig. 3 Effect of caerulein and bombesin $\left(10^{-10}\right.$ and $\left.10^{-8} \mathrm{M}\right)$ on the secretion of chymotrypsin, lipase and amylase from pancreatic fragments of $10 \mu \mathrm{g} / \mathrm{kg}$ bombesin treated (hatched columns) and untreated (open columns) rats. Results, expressed in percent of the spontaneous release, are means $\pm S E M$ of 6 experiments. NS: not significantly different.

When the release of enzymes was expressed per unit pancreatic weight (Fig. 4), there was a significant decrease of the release of lipase and amylase under basal and stimulated conditions (by caerulein and bombesin $10^{-8}$ and $10^{-10} \mathrm{M}$ ) in pancreases from bombesin treated rats when compared with saline treated. These results suggest that bombesin treatment lowers the functional capacity of individual pancreatic cells to release these enzymes. Indeed, the capacity of these cells to release chymotrypsin was similar in bombesin treated and untreated rats.
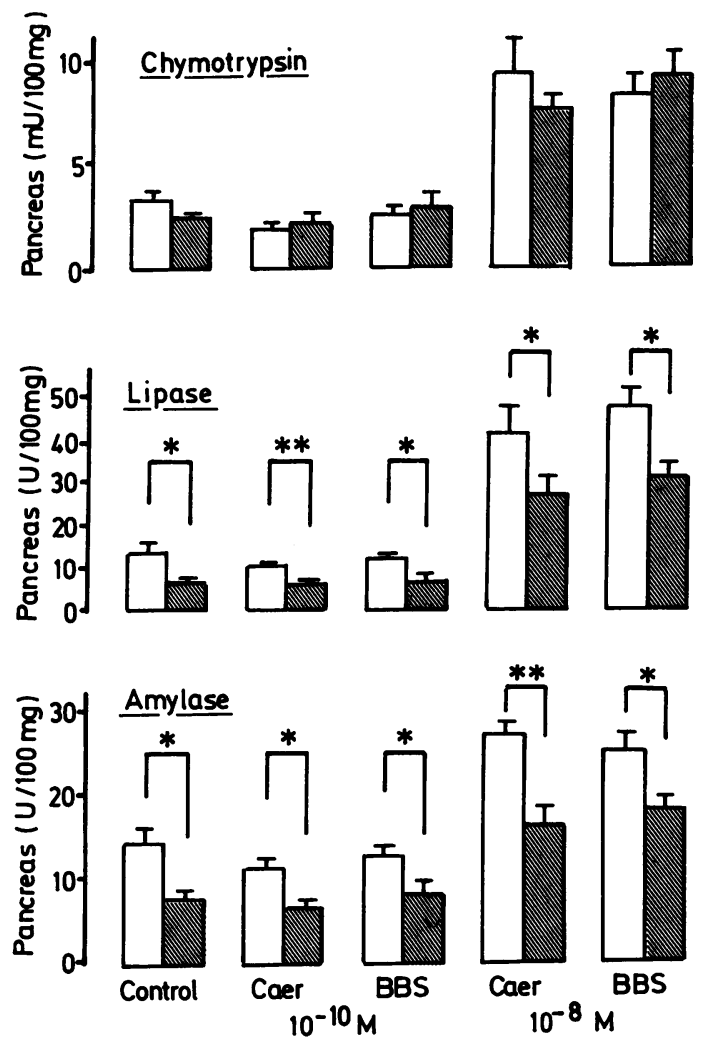

Fig. 4 Effect of caerulein and bombesin $\left(10^{-10}\right.$ and $\left.10^{-8} \mathrm{M}\right)$ on the secretion of chymotrypsin, lipase and amylase from pancreases of $10 \mu \mathrm{g} / \mathrm{kg}$ bombesin treated (hatched columns) and untreated (open columns) rats. Same experiments as indicated in Fig. 3. Results, expressed as enzyme activities per $100 \mathrm{mg}$ of pancreatic tissue, were means $\pm S E M$ of 6 experiments. ${ }^{*} p<0.05 ;{ }^{* *} p<0.01$.

\section{EFFECT OF CHRONIC BOMBESIN ON THE}

SECRETORY FUNCTION OF THE RAT PANCREAS IN VIVO

As illustrated in Figure 5, the volume of pancreatic secretion in saline treated rats increased respectively by $65 \%(\mathrm{NS})$ and $93 \%(\mathrm{p}<0.05)$ when CCK was injected intravenously at the doses of 5 and 10 IDU per $\mathrm{kg}$ under continuous infusion of secretin. A lower dose of CCK (1 IDU/kg) had no effect on this parameter. A quite similar secretory response has been observed in rats treated with $10 \mu \mathrm{g} / \mathrm{kg}$ bombesin. The output of enzymes, determined at $20 \mathrm{~min}$ intervals, also increased significantly after CCK administration at the doses of 5 and $10 \mathrm{IDU} / \mathrm{kg}$ (Fig. 6). Thus the outputs of chymotrypsin, lipase and amylase were respectively enhanced by $708 \%(p<0.05)$, $415 \%(p<0.05)$ and $122 \%(p<0.05)$ after 5 IDU/ $\mathrm{kg}$ CCK injection. Similar results were observed in 


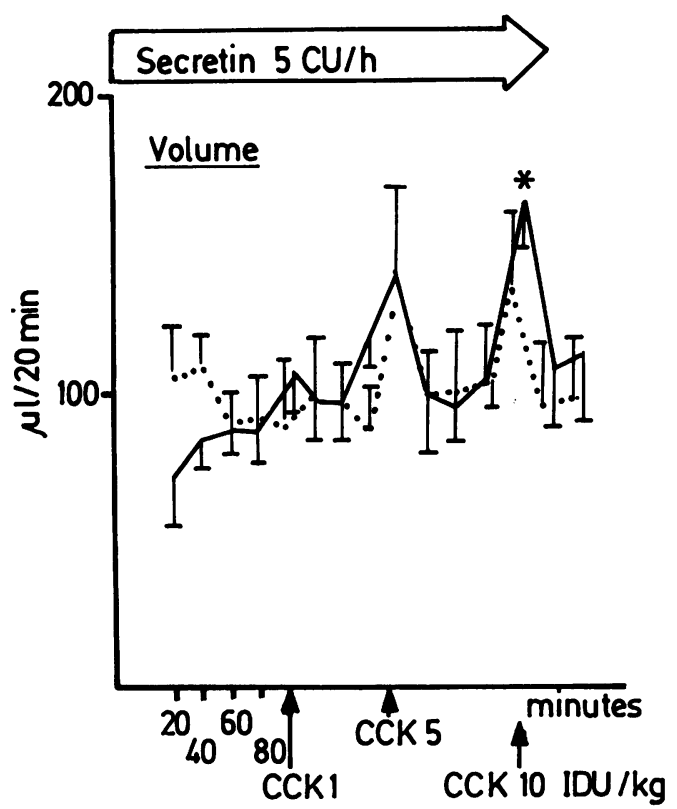

Fig. 5 Rate of pancreatic secretion in response to $C C K(1$, 5 and $10 \mathrm{IDU} / \mathrm{kg}$ ) under a continuous infusion of secretin $(5 \mathrm{CU} / \mathrm{h})$ in saline treated (full line) and bombesin treated (dotted line) animals. Results are means $\pm S E M$ of 6 animals. ${ }^{*} p<0.05$ when compared with basal values. bombesin treated rats. Thus bombesin treatment does not affect the secretory response of the pancreas to CCK under continuous infusion of secretin.

\section{Discussion}

It has been reported by Solomon $e t a^{6}$ that bombesin nonapeptide administered in the rat twice a day for seven days at the concentration of $9 \mu \mathrm{g} / \mathrm{kg}$ induces pancreatic growth. Bombesin tetradecapeptide administered in the same species three times daily and for five days exerts the same effect at the dose of $10 \mu \mathrm{g} /$ kg. ${ }^{57}$ Growth of the pancreas has been attributed to cellular hypertrophy after five days of repeated injections and hyperplasia after 15 days. ${ }^{7}$ Our present findings confirm these data and indicate that $10 \mu \mathrm{g} /$ $\mathrm{kg}$ bombesin, injected subcutaneously in the rat three times daily and for four days, provokes pancreatic growth characterised by an increase in pancreatic weight, its content in protein and RNA. Bombesin administered at lower doses, however, $(0 \cdot 1$ and $1 \mu \mathrm{g} /$ $\mathrm{kg}$ ) did not affect pancreatic size. In agreement with our previous results, ${ }^{57}$ the DNA content of the gland did not change after bombesin treatment suggesting the absence of hyperplasia. The ratios of pancreatic weight and its content in protein and RNA to DNA content of the gland increased significantly after a

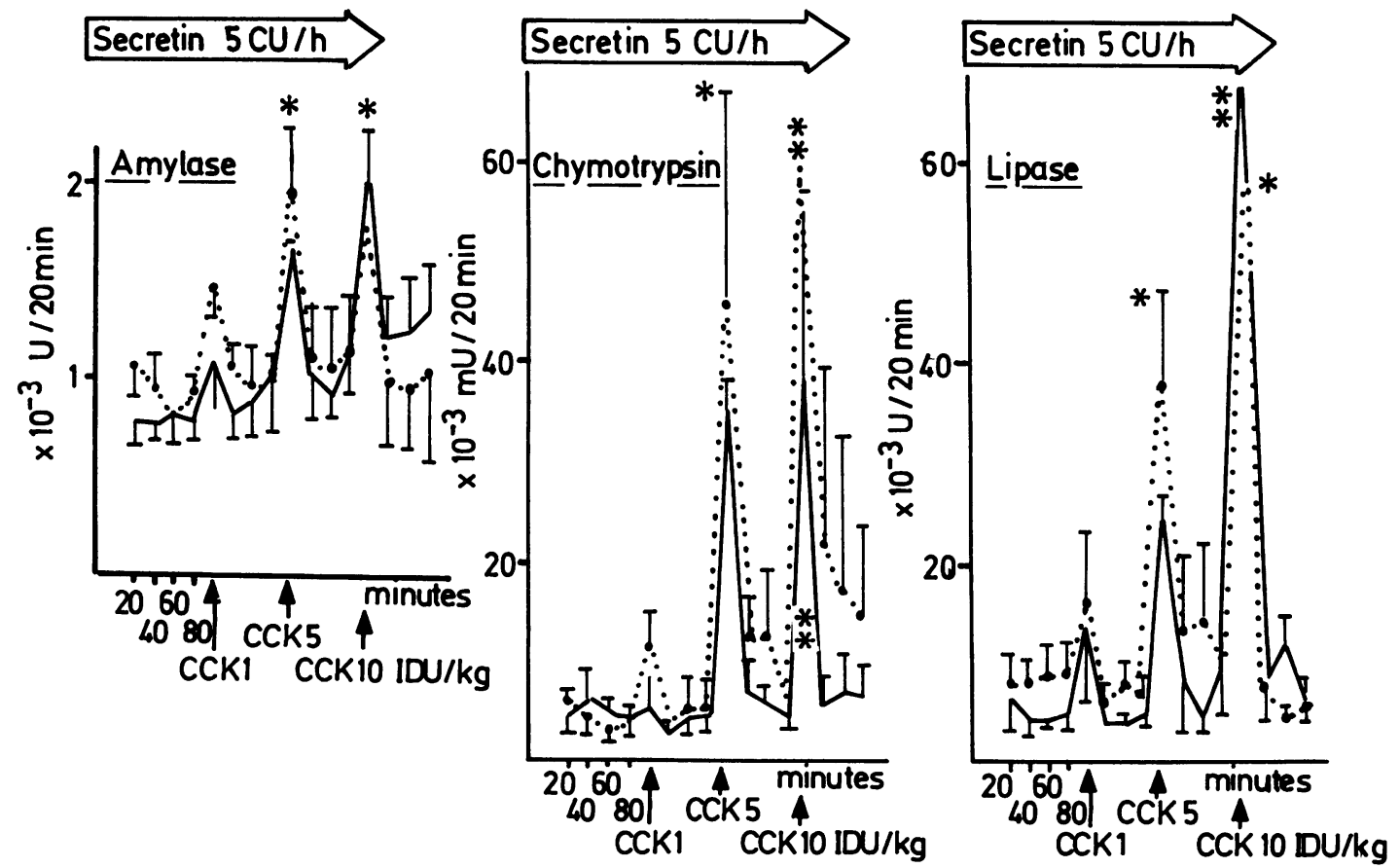

Fig. 6 Amylase, chymotrypsin and lipase outputs in response to CCK $(1,5$ and $10 \mathrm{IDU} / \mathrm{kg})$ under a continuous infusion of secretin $(5 \mathrm{CU} / \mathrm{h})$ in saline treated (full line) and bombesin treated (dotted line) animals. Results are means $\pm S E M$ of 6 animals. ${ }^{*} p<0.05{ }^{* *} p<0.01$ when compared with basal values. 
$10 \mu \mathrm{g} / \mathrm{kg}$ bombesin treatment suggesting cellular hypertrophy.

This work indicates also that chronic bombesin alters the enzymatic composition of the pancreas. As reported previously, ${ }^{7}$ repeated injections of $10 \mu \mathrm{g} / \mathrm{kg}$ bombesin, but not lower doses of this peptide, enhanced enzyme activities in the gland. The activity of chymotrypsin, however, was more raised than that of amylase and that of lipase. Such a pattern of changes has been already described after a long term treatment of rats with cholecystokinin ${ }^{2}$ suggesting that bombesin could act indirectly on the pancreas by the liberation of cholecystokinin. Bombesin has been shown to induce the liberation of a lot of gastrointestinal hormones including cholecystokinin..$^{1516}$ Several arguments are against this hypothesis. At first, proglumide, an agent known to block CCKreceptors on pancreatic cells, did not prevent the trophic action of bombesin on the rat pancreas. Secondly, secretin administered chronically in the rat together with bombesin, did not potentiate the trophic action of the latter on the pancreas ${ }^{5}$ while it potentiates pancreatic growth due to caerulein, a structural analogue of CCK. ${ }^{4}$ Thus it seems unlikely that bombesin induces pancreatic growth by stimulating the endogenous release of CCK. Another argument in favour of a different mode of action, at the cellular level, of bombesin and cholecystokinin originates from secretory studies.

According to Fölsch $e t a l^{2}$ and Petersen $e t a l,{ }^{3}$ rats treated chronically with CCK showed an increased secretory response of the pancreas to CCK. In contrast, the present findings indicate that pancreatic secretion in response to CCK under a continuous infusion of secretin was similar in bombesin and saline treated rats. These latter results may be explained by a reduced sensitivity of pancreatic cells to hormonal stimulation. Our in vitro secretory studies confirm this hypothesis. Indeed, the rate of secretion of amylase and lipase by individual pancreatic cells was lower in bombesin treated animals than in controls though the capacity of these cells to respond to a maximal stimulation by $10^{-8} \mathrm{M}$ bombesin or caerulein was maintained. A similar phenomenon has also been described by Petersen $e{ }^{a} l^{3}$ after secretin treatment: the maximal secretory responses to secretin and CCK were not different from controls. Thus, chronic treatment of rats with bombesin may possibly reduce the number of receptor sites available by an autoregulatory mechanism similar to that observed for insulin and growth hormone. ${ }^{17}$

In conclusion, bombesin can be considered as one of the peptides regulating pancreatic growth. Its chronic administration leads also to an increase in pancreatic enzyme composition but the secretory function of the gland remains unaltered. This pheno- menon could be explained by a mechanism of autoregulation, decreasing the sensitivity of each individual cell to secretagogues.

We are grateful to Miss G Balboni and Messrs A Hoeltzel, R Kurtz and A Hajri for their careful technical assistance.

\section{References}

1 Dembinski AB, Johnson LR. Stimulation of pancreatic growth by secretin, caerulein and pentagastrin. Endocrinology 1980; 106: 323-8.

2 Fölsch UR, Winckler K, Wormsley KG. Influence of repeated administration of cholecystokinin and secretin on the pancreas of the rat. Scand J Gastroenterol 1978; 13: $663-71$.

3 Petersen H, Solomon TE, Grossman MI. Effect of chronic pentagastrin, cholecystokinin and secretin on pancreas of rats. Am J Physiol 1978; 234: E286-93.

4 Solomon TE, Petersen H, Elashoff J, Grossman MI. Interaction of caerulein and secretin on pancreatic size and composition in rat. Am J Physiol 1978; 235: E7149.

5 Lhoste E, Aprahamian M, Pousse A, Hoeltzel A, StockDamgé. Combined effect of chronic bombesin and secretin or cholecystokinin on the rat pancreas. Peptides 1985; 6: suppl 3: 83-7.

6 Solomon TE, Petersen H, Elashoff J, Grossman MI. Effects of chemical messenger peptides on pancreatic growth in rats. In: Miyoshi A, ed. Gut peptides. Tokyo: Kodanska, 1979: 213-9.

7 Lhoste E, Aprahamian M, Pousse A, Hoeltzel A, StockDamgé C. Trophic effect of bombesin on the rat pancreas: is it mediated by the release of gastrin or cholecystokinin? Peptides 1985; 6: suppl 3: 89-97.

8 Campagne $R N$, Gruber $M$. Aminoacid and energy requirements of protein synthesis in rat pancreatic tissue in vitro. Biochim Biophys Acta 1962; 55: 353-60.

9 Bradford MM. A rapid and sensitive method for the quantitation of microgram quantities of protein utilizing the principle of protein-dye binding. Anal Biochem 1976; 72: $248-54$

10 Richards GM. Modifications of the diphenylamine reaction giving increased sensitivity and simplicity in the estimation of DNA. Anal Biochem 1974; 57: 36976.

11 Schneider WC. Determination of nucleic acids in tissues by pentose analysis. In: Colowick SP, Kaplan NO, eds Methods of enzymology. New York: Academic Press, 1957: 680-4.

12 Danielsson A. Technique for measuring amylase secretion from pieces of mouse pancreas. Anal Biochem 1974; 59: 220-34.

12 Nagel W, Willig F, Peschke W, Schmidt FH. Uber die Bestimmung von Trypsin und Chymotrypsin mit Aminosäure-p-nitroaniliden. Hoppe Seylers Z Physiol Chem $1965 ; 340$ : 1-10.

14 Verduin PA, Punt JMHM, Kreutzer HH. Studies on the determination of lipase activity. Clin Chim Acta 1973; 46: 11-9. 
15 Miyata M, Rayford PL, Thompson JC. Hormonal (gastrin, secretin, cholecystokinin) and secretory effects of bombesin and duodenal acidification in dogs. Surgery 1980; 87: 209-15.

16 Ghatei MA, Jung RT, Stevenson JC, Hillyard CJ, Adrian TE, Lee YC, Christofides ND, Sarson DL,
Nashiter K, MacIntire I, Bloom SR. Bombesin action on gut hormones and calcium in man. J Clin Endocrinol Metab 1982; 54: 980-5.

17 Lesniack MA, Roth J. Regulation of receptor concentration by homologous hormone. J Biol Chem 1976; 251: 3720-9. 